\title{
Bioconversion of paper sludge to biofuel by simultaneous saccharification and fermentation using a cellulase of paper sludge origin and thermotolerant Saccharomyces cerevisiae TJ14
}

\author{
Joni Prasetyo ${ }^{1}$, Kazuya Naruse ${ }^{2}$, Tatsuya Kato ${ }^{2}$, Chuenchit Boonchird ${ }^{3}$, Satoshi Harashima ${ }^{4}$ and Enoch Y Park , $^{1 *}$
}

\begin{abstract}
Background: Ethanol production from paper sludge (PS) by simultaneous saccharification and fermentation (SSF) is considered to be the most appropriate way to process PS, as it contains negligible lignin. In this study, SSF was conducted using a cellulase produced from PS by the hypercellulase producer, Acremonium cellulolyticus C-1 for PS saccharification, and a thermotolerant ethanol producer Saccharomyces cerevisiae TJ14 for ethanol production. Using cellulase of PS origin minimizes biofuel production costs, because the culture broth containing cellulase can be used directly.

Results: When $50 \mathrm{~g}$ PS organic material (PSOM)/I was used in SSF, the ethanol yield based on PSOM was 23\% ( $\mathrm{g}$ ethanol/g PSOM) and was two times higher than that obtained by a separate hydrolysis and fermentation process. Cellulase activity throughout SSF remained at around 60\% of the initial activity. When 50 to $150 \mathrm{~g}$ PSOM/I was used in SSF, the ethanol yield was 21\% to 23\% (g ethanol/g PSOM) at the $500 \mathrm{ml}$ Erlenmeyer flask scale. Ethanol production and theoretical ethanol yield based on initial hexose was $40 \mathrm{~g} / \mathrm{l}$ and $66.3 \%$ (g ethanol/g hexose) at 80 h, respectively, when $161 \mathrm{~g} / \mathrm{I}$ of PSOM, 15 filter paper units (FPU)/g PSOM, and 20\% inoculum were used for SSF, which was confirmed in the 2 I scale experiment. This indicates that PS is a good raw material for bioethanol production.

Conclusions: Ethanol concentration increased with increasing PSOM concentration. The ethanol yield was stable at PSOM concentrations of up to $150 \mathrm{~g} / \mathrm{l}$, but decreased at concentrations higher than $150 \mathrm{~g} / \mathrm{l}$ because of mass transfer limitations. Based on a 2 I scale experiment, when 1,000 kg PS was used, 3,182 kFPU cellulase was produced from $134.7 \mathrm{~kg}$ PS. Produced cellulase was used for SSF with $865.3 \mathrm{~kg}$ PS and ethanol production was estimated to be $51.1 \mathrm{~kg}$. Increasing the yeast inoculum or cellulase concentration did not significantly improve the ethanol yield or concentration.
\end{abstract}

\section{Background}

Recently, much research has been conducted on reducing the input energy and cost of ethanol production. Around 5 million tons of paper sludge (PS) is discharged annually by the paper manufacturing industry in Japan. Disposing of PS in landfill or by incineration creates environmental problems, and legislative trends

\footnotetext{
* Correspondence: acypark@ipc.shizuoka.ac.jp

'Laboratory of Biotechnology, Integrated Bioscience Section, Graduate School of Science and Technology, Shizuoka University, 836 Ohya, Suruga-ku, Shizuoka 422-8017, Japan

Full list of author information is available at the end of the article
}

in many countries are restricting the amount and types of materials that are permitted to be disposed of by landfill [1]. The production of bioethanol from PS can reduce dependence on fossil fuels while simultaneously solving the environmental problems associated with PS disposal. The use of bioethanol produced from PS offers an alternative source of energy, which could help overcome the current fossil fuel crisis and slow global warming. Using industrial waste materials as raw materials for bioethanol production is increasingly being researched $[2,3]$, due to the lower costs of raw materials and to avoid competition with human needs occurring when

\section{C) Biomed Central}

(C) 2011 Prasetyo et al; licensee BioMed Central Ltd. This is an Open Access article distributed under the terms of the Creative Commons Attribution License (http://creativecommons.org/licenses/by/2.0), which permits unrestricted use, distribution, and reproduction in any medium, provided the original work is properly cited. 
food crops are used, as is the case for first generation production processes.

Recent research into ethanol production from PS has been reported, using pretreatments such as mechanical grinding or phosphoric acid swelling to improve saccharification yield and efficiency [4]. To remove hemicelluloses in the lignocellulosic material contained in recycled PS and cotton gin waste, mixing with steam treatment has been described as an effective pretreatment. However, this pretreatment method generated compounds that are toxic to the microorganism responsible for fermentation. Some inhibitors, such as furfural and hydroxymethylfurfural that are derivatives of lignin, significantly influence the performance of cellulase and ethanol fermentation by yeast $[5,6]$. By using recycled PS that contains calcium carbonate (overliming), the toxic compounds can be eliminated [7]. An advantage of PS as a carbon source over other lignocellulosic materials in bioethanol production is that pretreatment is not required, since most of the lignin has already been removed during the pulping that forms part of the paper manufacturing process.

The conventional yeast used in anaerobic alcohol fermentation releases $8.1 \mathrm{~kJ} / \mathrm{C}$ mol glucose and cannot degrade xylose [8], which constitutes more than $10 \%$ of the reducing sugars (RS) contained in PS. When carrying out the process on an industrial scale, the bioreactor culture temperature must be controlled using cooling water. Using thermotolerant yeast reduces the costs involved in cooling the fermentation, as well as costs associated with the distillation of ethanol.

Ethanol concentration is an important factor of biofuel production, and should be at least $40 \mathrm{~g} / \mathrm{l}$ in order to decrease the energy required during the ethanol separation and purification processes [9]. In order to achieve ethanol concentrations of $40 \mathrm{~g} / \mathrm{l}$, research has been conducted into enabling ethanol production in semicontinuous fed-batch reactors. Starting ethanol concentrations of about $20 \mathrm{~g} / \mathrm{l}$ have been reported, with the concentration reaching $40 \mathrm{~g} / \mathrm{l}$ after $36 \mathrm{~h}$ [10]. Solid-state fed-batch fermentation processes conducted in a rotary drum have been shown to be an alternative method, and the gas phase containing ethanol was collected as its condensate at $-10^{\circ} \mathrm{C}[11]$.

Most ethanol production from cellulosic biomass has been conducted using commercial cellulases. However, the potential to use PS as a carbon source using a cellulase produced by Acremonium cellulolyticus has already been shown [12]. This fresh cellulase, which was produced using PS as carbon source can be used directly to hydrolyse PS organic material (PSOM) that contains cellulose and hemicellulose. Only simple separation processes to remove insoluble materials such as clay and other biomass are required. In the present study, we established efficient bioethanol production using cellulase produced from PS and thermotolerant Saccharomyces cerevisiae TJ14 in a simple process without any pretreatment of PS. To allow for comparison, Solka Floc (SF), which is composed entirely of cellulose, was used in separate hydrolysis and fermentation (SHF) and simultaneous saccharification and fermentation (SSF) processes for ethanol production. The performance of the process was evaluated and optimized to achieve a high ethanol concentration from PS for use as a biofuel.

\section{Methods}

\section{Raw materials}

PS was provided by Tomoegawa Co. Ltd. (Shizuoka, Japan). The PS was collected from a primary clarifier sludge dewatering process used for the production of virgin wood fiber, which was a mixture of pine, cypress and eucalyptus. This PS contained 65\% water, 10.5\% clay, $24.5 \%$ organic material and $1.2 \mathrm{mg} \mathrm{RS} / \mathrm{g}$ wet PS on a weight basis [1]. The clay composition is shown in detail in Table 1[13]. Dry PS contained 30\% clay and $66 \%$ organic material consisting of cellulose and hemicellulose. Glucan and mannan levels in the hydrolysate of this PS organic material (PSOM) were $64.5 \%$ and 2.5\%, respectively (Table 2). SF (CAS \#9004-34-6; International Fiber Co., New York, NY, USA) was used as positive control for cellulose. SF is a fine white powder comprised of approximately $70 \%$ to $80 \%$ crystalline cellulose and $20 \%$ to $30 \%$ amorphous cellulose. Acremozyme cellulase was purchased from Meiji Seika Kaisha, Ltd. (Tokyo, Japan). Glucose, xylose, mannose and other chemicals were purchased from Wako Pure Chem. Co. Ltd. (Tokyo, Japan) and stored at room temperature.

\section{Microorganisms}

A. Cellulolyticus C-1 (Ferm P-18508), which is a hypercellulase producer and a mutant of wild-type A. cellulolyticus Y-94, was provided by Tsukishima Kikai Co. Ltd. (Tokyo, Japan) [14]. A. cellulolyticus produces a complex

Table 1 Chemical composition of representative paper sludge (PS) ash [13]

\begin{tabular}{ll}
\hline Ash & Composition (\% w/w) \\
\hline $\mathrm{SiO}_{2}$ & 35.7 \\
$\mathrm{TiO}_{2}$ & 1.2 \\
$\mathrm{Al}_{2} \mathrm{O}_{3}$ & 26 \\
$\mathrm{FeO}^{\mathrm{a}}$ & 0.4 \\
$\mathrm{MnO}$ & 0 \\
$\mathrm{MgO}$ & 8 \\
$\mathrm{CaO}$ & 25.7 \\
$\mathrm{Na}$ & 0.1 \\
$\mathrm{~K}_{2} \mathrm{O}$ & 0.1 \\
\hline
\end{tabular}

${ }^{\mathrm{a}}$ Total iron as $\mathrm{FeO}$. 
Table 2 Composition of dry paper sludge (PS)

\begin{tabular}{ll}
\hline Component & Amount $(\mathbf{g} / \mathbf{g}$ dry PS) \\
\hline Total sugar & 0.66 \\
Glucan & 0.44 \\
Mannan & 0.02 \\
$\quad$ Xylan & 0.07 \\
Other sugars & 0.13 \\
Clay & 0.30 \\
Others & 0.04 \\
\hline
\end{tabular}

mixture of cellulases, mainly comprised of $4 \beta$-glucosidases (EC 3.2.1.21) and 12 distinct endocellulase/carboxymethyl cellulase (CMCases, EC 3.2.1.4) $[15,16]$. Other polysaccharide hydrolyzing enzymes, such as xylanases, amylases and $\beta$-1,3-glucanases, were also present [14]. The most important enzyme in this mixture with regard to the current process is an endocellulose type III-A that can produce glucose from cellulose with no involvement of $\beta$-glucosidase [16].

A thermotolerant strain of S. cerevisiae, TJ14 [17], was used in this study. S. cerevisiae TJ14 is a hybrid strain between the heat-tolerant strain HB8(RI)-3A (MATahis $3 \Delta 1$ leu $2 \Delta 0$ ura3 $\Delta 0$ ) and an ethanol producer yeast TISTR5056, generated by spore-to-cell mating. HB8 (RI)-3A is a derivative strain from a natural thermotolerant yeast isolate (C3723) found in Thailand and a thermosensitive laboratory yeast strain BY4742

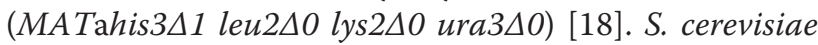
TJ14 can be precultivated aerobically by shaking at 200 rpm [12].

\section{Fermentation media and cultivations}

The preculture medium for $A$. cellulolyticus consisted (per liter) of $40 \mathrm{~g} \mathrm{SF}, 24 \mathrm{~g}$ of $\mathrm{KH}_{2} \mathrm{PO}_{4}, 1 \mathrm{ml}$ of Tween 80 (MP Biomedicals, Solon, OH, USA), $5 \mathrm{~g}$ of $\left(\mathrm{NH}_{4}\right)$ ${ }_{2} \mathrm{SO}_{4}, 4.7 \mathrm{~g}$ of $\mathrm{K}_{2} \mathrm{C}_{4} \mathrm{H}_{4} \mathrm{O}_{6} \cdot 4 \mathrm{H}_{2} \mathrm{O}, 1.2 \mathrm{~g}$ of $\mathrm{MgSO}_{4} \cdot 7 \mathrm{H}_{2} \mathrm{O}$, $10 \mathrm{mg}$ of $\mathrm{ZnSO}_{4} \cdot 7 \mathrm{H}_{2} \mathrm{O}, 9.28 \mathrm{mg}$ of $\mathrm{MnSO}_{4} \cdot 7 \mathrm{H}_{2} \mathrm{O}, 8.74$ mg of $\mathrm{CuSO}_{4} \cdot 7 \mathrm{H}_{2} \mathrm{O}$ and $2 \mathrm{~g}$ of urea $(\mathrm{pH} 4.0)$. The medium was sterilized at $121^{\circ} \mathrm{C}$ for $20 \mathrm{~min}$, with $\mathrm{ZnSO}_{4} \cdot 7 \mathrm{H}_{2} \mathrm{O}, \mathrm{MnSO}_{4} \cdot 7 \mathrm{H}_{2} \mathrm{O}$ and $\mathrm{CuSO}_{4} \cdot 7 \mathrm{H}_{2} \mathrm{O}$ sterilized separately. Urea was sterilized by filtering through a $0.45 \mu \mathrm{m}$ filter membrane (Toyo Roshi Kaisha Co. Ltd., Tokyo, Japan). The cellulase production medium was comprised of $70 \mathrm{~g}$ PSOM/l as carbon source without the addition of any further minerals other than those contained in PS. $\mathrm{KH}_{2} \mathrm{PO}_{4}$ and urea were added at final concentrations of $10 \mathrm{~g} / \mathrm{l}$ and $4 \mathrm{~g} / \mathrm{l}$, respectively. Cultures were conducted in a 31 jar fermenter equipped with a Labo-controller (MDL-80, Marubishi, Tokyo Japan) with a 1.21 working volume. The culture broth was centrifuged at 9,447 $g$ and the supernatant was stored in a $4^{\circ}$ $\mathrm{C}$ refrigerator. The activity of the cellulase was analyzed before use in the enzymatic hydrolysis of PSOM.
The inoculums of $S$. cerevisiae TJ14 was carried out in $50 \mathrm{~g} / \mathrm{l}$ yeast/peptone/dextrose (YPD) medium containing less than $0.04 \%$ of adenine (Sigma-Aldrich Co. Ltd., St Louis, MO, USA). The YPD medium was composed of $20 \mathrm{~g} / \mathrm{l}$ of bacteriological peptone, $10 \mathrm{~g} / \mathrm{l}$ of yeast extract and $20 \mathrm{~g} / \mathrm{l}$ of glucose. This seed culture was incubated for 24-30 $\mathrm{h}$ and by this time the cell density was about 2.2 to 2.8 g dry cell weight (DCW)/l. The fermentation was carried out by adding $10 \%(\mathrm{v} / \mathrm{v})$ inoculum. The ethanol production medium was comprised (per liter) of $4 \mathrm{~g} \mathrm{KH}_{2} \mathrm{PO}_{4}, 2.5 \mathrm{~g}\left(\mathrm{NH}_{4}\right)_{2} \mathrm{SO}_{4}, 0.6 \mathrm{~g} \mathrm{MgSO}_{4} \cdot 7 \mathrm{H}_{2} \mathrm{O}, 2.35$ g $\mathrm{K}_{2} \mathrm{C}_{4} \mathrm{H}_{4} \mathrm{O}_{6} \cdot 4 \mathrm{H}_{2} \mathrm{O}, 1.0 \mathrm{~g} \mathrm{CaCl}_{2} \cdot 2 \mathrm{H}_{2} \mathrm{O}, 5$ g yeast extract and $10 \mathrm{~g}$ of polypeptone. Glucose was used as a carbon source during fermentation. In the case of ethanol production from PS, the medium was comprised (per liter) of PS, $5 \mathrm{~g}$ yeast extract, $10 \mathrm{~g}$ of polypeptone and $4 \mathrm{~g}$ $\mathrm{KH}_{2} \mathrm{PO}_{4}$ in $0.2 \mathrm{M}$ maleic buffer. The quantity of PS used was varied for each experiment.

\section{Optimization of saccharification}

PSOM was hydrolyzed in $500 \mathrm{ml}$ Erlenmeyer flasks in a reciprocal shaker at an agitation rate of $110 \mathrm{rpm}$ for 120 $\mathrm{h}$ at $42^{\circ} \mathrm{C}$ in $0.8 \mathrm{M}$ maleate buffer with initial $\mathrm{pH} 5.2$ [1]. The PSOM concentrations were varied 10, 30, 50, 70, 90, $110 \mathrm{~g} / \mathrm{l}$ in maleate buffer. For the saccharification reaction, the Acremozyme cellulase (Meiji Seika Kaisha) used had an activity of 5, 10, 20, 40, 60, 80, 100 filter paper units (FPU)/g PSOM. Samples were taken every $12 \mathrm{~h}$ and centrifuged at 9,447 $g$ for $5 \mathrm{~min}$. The reaction was stopped by boiling the samples for $5 \mathrm{~min}$ and then measuring the RS content of the supernatant. Data were analyzed by Design Expert (v. 7.1.6, Stat-Ease, Minneapolis, MN, USA).

The percent saccharification yield $\left(Y_{\mathrm{s}}\right)$ of substrates in terms of the RS concentration was calculated by the formula:

$$
Y_{s}=\frac{\text { Reducing sugar concentration }(\mathrm{g} / \mathrm{l}) \times \text { Hydrolysate volume }(\mathrm{l})}{\text { PS weight }(\mathrm{g}) \times \mathrm{PSOM} \text { content in the PS }(\% \mathrm{w} / \mathrm{w})} \times 100
$$

using a PSOM content of $24.5 \%$.

\section{Separate hydrolysis fermentation and simultaneous saccharification fermentation}

SHF involves enzymatic hydrolysis and fermentation, and these were carried out in $500 \mathrm{ml}$ Erlenmeyer flasks with a working volume of $100 \mathrm{ml}$. The PSOM was hydrolysed by cellulase produced from PSOM as carbon source until a maximum RS concentration was achieved. A total of $5 \mathrm{~g} / \mathrm{l}$ of yeast extract, $10 \mathrm{~g} / \mathrm{l}$ polypeptone and $4 \mathrm{~g} / \mathrm{l} \mathrm{KH}_{2} \mathrm{PO}_{4}$ were added to the hydrolysate and this mixture was used as the fermentation medium. The medium was also sterilized to deactivate the cellulase prior to fermentation. After the sterilized medium had been cooled to $42^{\circ} \mathrm{C}$, it was inoculated with $10 \%(\mathrm{v} / \mathrm{v})$ of 
the yeast preculture and incubated with agitation at 5080 strokes per min (spm) in a reciprocal shaker (Bioshaker TA-25R, Takasaki Scientific Instruments, Saitama, Japan) and $42^{\circ} \mathrm{C}$.

A schematic diagram of SSF using PS as the carbon source for cellulase production and as a substrate for saccharification by the cellulase produced is shown in Figure 1. PSOM was used as a carbon source for cellulase production by $A$. cellulolyticus $\mathrm{C}-1$ at $28^{\circ} \mathrm{C}$. The culture broth containing the cellulase was separated from the A. cellulolyticus culture, and used for saccharification of PS in SSF at $42^{\circ} \mathrm{C}$. In SSF, ethanol fermentation was carried out simultaneously with saccharification of PS by inoculation with yeast. Medium compositions (per liter) for SSF consisted of PSOM, 5 g yeast extract, $10 \mathrm{~g}$ polypeptone and $4 \mathrm{~g} \mathrm{KH}_{2} \mathrm{PO}_{4}$.
For improving ethanol concentration, PSOM concentration and cellulase activity were optimized using the following conditions: initial PSOM concentrations were 50, 80 and $110 \mathrm{~g} / \mathrm{l}$ and cellulase activities were 15, 25 and $35 \mathrm{FPU} / \mathrm{g}$ PSOM. After medium sterilization, the cellulase and $10 \%$ inoculum were added to $500 \mathrm{ml}$ Erlenmeyer flasks with final working volumes of $100 \mathrm{ml}$. When $170 \mathrm{~g} / \mathrm{l}$ of PSOM and $35 \mathrm{FPU} / \mathrm{g}$ PSOM were used, the culture could not be readily mixed. To avoid the mixing problem, the PSOM was added at 0 and $8 \mathrm{~h}$ of culture time as follows: $8.5 \mathrm{~g}$ of PSOM (PS $34.7 \mathrm{~g}$ containing $22.5 \mathrm{ml}$ of water), $14 \mathrm{ml}$ of cellulase solution, $10 \mathrm{ml}$ of inoculum, and $21 \mathrm{ml}$ of buffer (total working volume of $67.5 \mathrm{ml}$ ), and at the culture time of $8 \mathrm{~h}$, another 8.5 g PSOM (PS $34.7 \mathrm{~g}$ containing $22.5 \mathrm{ml}$ of water) and $10 \mathrm{ml}$ of cellulase solution were added. The

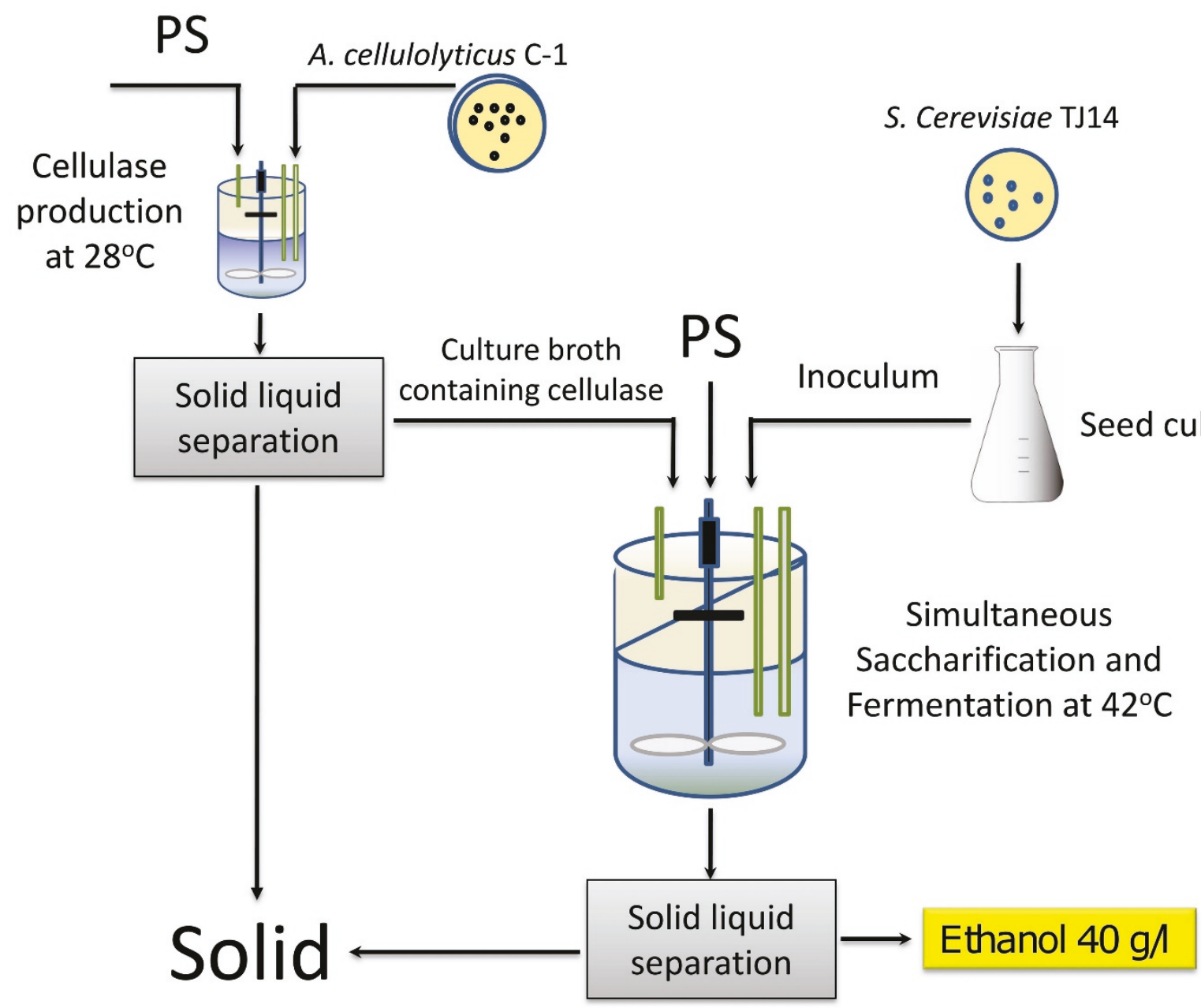

Figure 1 Schematic diagram of simultaneous saccharification and fermentation (SSF) using cellulose of paper sludge (PS) origin and thermotolerant Saccharomyces cerevisiae TJ14. PS was used as a carbon source for cellulase production by Acremonium cellulolyticus C-1 at $28^{\circ} \mathrm{C}$. The culture broth containing cellulase was separated from the A. cellulolyticus culture and used for saccharification of PS in SSF at $42^{\circ} \mathrm{C}$. Ethanol fermentation was carried out by inoculation with yeast simultaneously with saccharification of PS during SSF. After SSF, the ethanol solution was separated from the SSF culture broth. 
final working volume was $100 \mathrm{ml}$. The PSOM concentration was $126 \mathrm{~g} / \mathrm{l}$ at $0-8 \mathrm{~h}$ of culture time, and $170 \mathrm{~g} / \mathrm{l}$ after $8 \mathrm{~h}$ of culture time.

To improve ethanol production in SSF, the amount of PSOM was increased with $15 \mathrm{FPU} / \mathrm{g}$ PSOM of cellulase. Due to mixing problems, the initial concentration was $80 \mathrm{~g}$ PSOM/l, and $11 \mathrm{~g}$ PSOM (44.9 g PS) and PS cellulase $15 \mathrm{FPU} / \mathrm{g}$ PSOM were added on one, two or three occasions at culture times of $8 \mathrm{~h}, 16 \mathrm{~h}$, and $20 \mathrm{~h}$, respectively. The final PSOM concentration was therefore 127, 151 and $165 \mathrm{~g}$ PSOM/l in each case. The SSF was conducted at $42^{\circ} \mathrm{C}$ until a maximum ethanol concentration was reached with agitation at 50-80 spm in a reciprocal shaker (Bioshaker TA-25R, Takasaki Scientific Instruments).

To improve ethanol yield, the inoculum was increased from $10 \%$ to $20 \%$ when the following conditions were used: $100 \mathrm{~g} / \mathrm{l}$ of initial PSOM with $15 \mathrm{FPU} / \mathrm{g}$ PSOM, then $11 \mathrm{~g}$ PSOM added at culture times of 8 and $16 \mathrm{~h}$. All PS used in the above experiments was sterilized to avoid contamination in the fermentation, and fermentation was stopped when the ethanol concentration reached a maximum. After SSF, the ethanol solution was separated from insoluble material of SSF culture broth. The supernatant was refrigerated at $4^{\circ} \mathrm{C}$ for measurement of RS, glucose, ethanol concentrations and remaining cellulase activity.

Scale up of SSF was carried out in 21 Erlenmeyer flask with a working volume of $1.2 \mathrm{l}$. The initial composition of SSF was 100 PSOM g/l and 15 FPU/g PSOM, and the SSF was started with $20 \%$ inoculum in $600 \mathrm{ml}$. An additional $66 \mathrm{~g}$ of PSOM and $15 \mathrm{FPU} / \mathrm{g}$ PSOM of cellulase were added twice at culture times of $8 \mathrm{~h}$ and $16 \mathrm{~h}$, and then final working volume adjusted to $1.2 \mathrm{l}$.

Since the consumed concentrations of hexose and PSOM during the reaction were unknown, theoretical ethanol yield based on initial hexose $\left(Y_{e / h e x}\right)$ was defined as follows:

$$
Y_{e / h e x}=\frac{\Delta C_{e}}{C_{e / h e x}} \times 100
$$

where $\Delta C_{e}$ indicates produced ethanol concentration during the process. $C_{e / h e x}$ indicates theoretical ethanol concentration converted from hexose containing in PSOM as follows:

$$
C_{e / h e x}=0.66 \times C_{p s o m} \times 1.11 \times 0.51
$$

where $C_{p s o m}$ denote initial PSOM concentrations $(\mathrm{g} / \mathrm{l})$. Constants 1.11 and 0.51 denote coefficients from hydrolysis of glucan and from hexose to ethanol, respectively.

When consumed glucose concentration $\left(\Delta C_{g l c}\right)$ was measured, theoretical ethanol yield $\left(Y_{e / g l c}\right)$ was defined as follows:

$$
Y_{e / g l c}=\frac{\Delta C_{e}}{\Delta C_{g l c} \times 0.51} \times 100
$$

For the practical ethanol production from PS, the ethanol yield based on the initial PSOM $\left(Y_{\text {e/psom }}\right)$ is as follows:

$$
Y_{e / p s o m}=\frac{\Delta C_{e}}{C_{p s o m}} \times 100
$$

\section{Analysis methods}

In the case of soluble substrate, the DCW of the microorganism was determined by centrifuging the cell broth at 5,000 $\mathrm{g}$ for $15 \mathrm{~min}$. The harvested cells were resuspended in distilled water and centrifuged again to remove medium components [19]. The precipitate was dried at $105^{\circ} \mathrm{C}$. In the case of PS that contained insoluble material, viable cell numbers were determined by counting colony-forming units (CFU) on an agar plate containing $1.5 \%$ agar. The CFU was converted to DCW $\left(1.6 \times 10^{7}\right.$ viable cell/g DCW $)$ using a calibration curve. Due to the difficulty in separating the mycelia of $A$. cellulolyticus $\mathrm{C}-1$ from the medium, intercellular nucleic acid concentration (INA) was measured and converted to dry cell weight $(\mathrm{DCW})$ as follows [17]"

$$
\begin{aligned}
& I N A(g / l)=1.72 \times \text { absorbance at } 260 \mathrm{~nm} \\
& \operatorname{DCW}(\mathrm{g} / \mathrm{l})=16.565 \times I N A
\end{aligned}
$$

Cellulase activity was measured using the standard International Union of Pure and Applied Chemistry (IUPAC) procedure with Whatman no. 1 filter paper, and the activity was expressed in FPU. The FPU unit is based on the International Unit (IU) in which the absolute amount of glucose at a critical dilution is $2 \mathrm{mg}$ for $0.5 \mathrm{ml}$ critical enzyme concentration in $60 \mathrm{~min}$ [20].

The monosaccharide content was analyzed by highperformance liquid chromatography (HPLC; PU-980; JASCO Co. Ltd., Tokyo, Japan). Detection was carried out using a refractive index detector (RI-930, JASCO) and an amine-modified silica column (Shodex Asahipack NH2P-50 4E, 4.6 diameter, 250 mm, Shimadzu GLC Ltd., Tokyo, Japan) in combination with a precolumn. The mobile phase was $75 \%$ acetonitrile, and the flow rate was $1 \mathrm{ml} / \mathrm{min}$. The total sugar content of PS was determined according to the standard National Renewable Energy Laboratory (NREL) method [21]. PS was dried at $80^{\circ} \mathrm{C}$ and treated with $72 \% \mathrm{H}_{2} \mathrm{SO}_{4}$ for $1 \mathrm{~h}$ at $30^{\circ}$ $\mathrm{C}$, then diluted with $4 \% \mathrm{H}_{2} \mathrm{SO}_{4}$ and autoclaved for $1 \mathrm{~h}$ at $121^{\circ} \mathrm{C}$. Glucose and mannose concentrations were analyzed with Megazyme kits (Biocon (Japan) Ltd., Nagoya, Japan) while the RS content of the medium was determined by the dinitrosalicylic acid method. 
Ethanol concentration was measured using gas chromatography (GC) (Shimadzu-2014, Shimadzu Co. Ltd., Tokyo, Japan) using a packed column (Gaskuropack 54 60/80, GC-2014 Glass ID. 3.2 diameter $\times 2.1 \mathrm{~m}$, GL Science Co. Ltd., Tokyo, Japan), with the following operational conditions: temperature of column and detector were $110^{\circ} \mathrm{C}$ and $250^{\circ} \mathrm{C}$, respectively; nitrogen gas flow rate was $60 \mathrm{ml} / \mathrm{min}$; injected sample volume was $2 \mu \mathrm{l}$.

\section{Results}

\section{Ethanol production from monosaccharide}

The monosaccharides contained in the enzymatic hydrolysate of PS are glucose, xylose, mannose and arabinose (Figure 2A). Other monosaccharides were present in negligible concentrations $(<1 \%)$. When $20 \mathrm{~g} / \mathrm{l}$ of glucose, mannose and xylose were used as carbon sources, ethanol production from glucose and mannose were $8.60 \mathrm{~g} / \mathrm{l}$ and $8.46 \mathrm{~g} / \mathrm{l}$, respectively (Figure $2 \mathrm{~B}$ ). The $Y_{\mathrm{e} / \mathrm{glc}}$ of glucose and mannose were 93 and $92 \%$, respectively. The $S$. cerevisiae TJ14 strain did not consume xylose for ethanol production, and the ethanol concentration generated from xylose was almost $0 \mathrm{~g} / \mathrm{l}$ (Figure $2 \mathrm{~B})$. Although xylose is consumable, the ethanol yield is considerably lower than that obtained from glucose [4]. When a $10 \mathrm{~g} / \mathrm{l}$ of glucose and mannose mixture at ratio of 85:15 was used as the carbon source, the ethanol concentration was $5.1 \mathrm{~g} / \mathrm{l}$ and the $Y_{\mathrm{e} / \mathrm{glc}}$ was $87.8 \%$ (Figure $2 \mathrm{C})$, which corresponds to a $88 \%$ theoretical ethanol yield [22]. When the initial glucose concentration was less than $150 \mathrm{~g} / \mathrm{l}$ in the culture of $S$. cerevisiae TJ14, the $Y_{\text {e/glc }}$ was $88 \%$ to $94 \%$ (g/g) (data not shown).

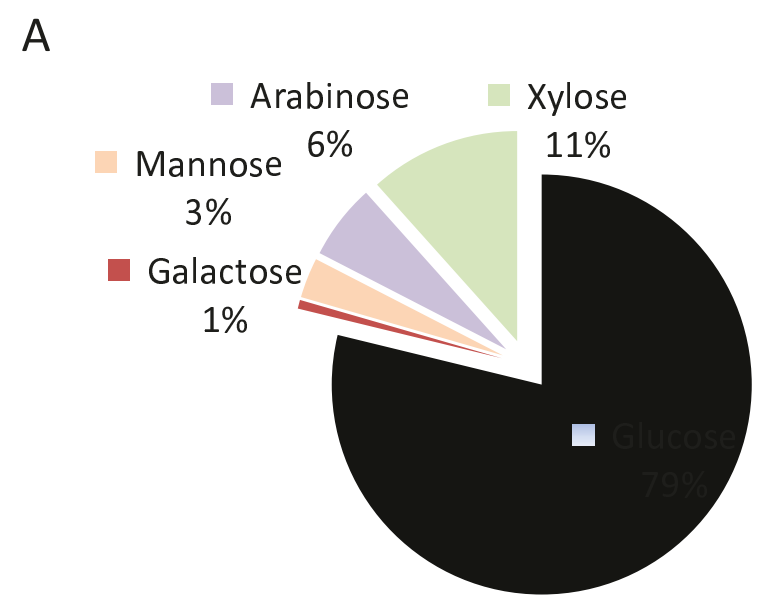

B

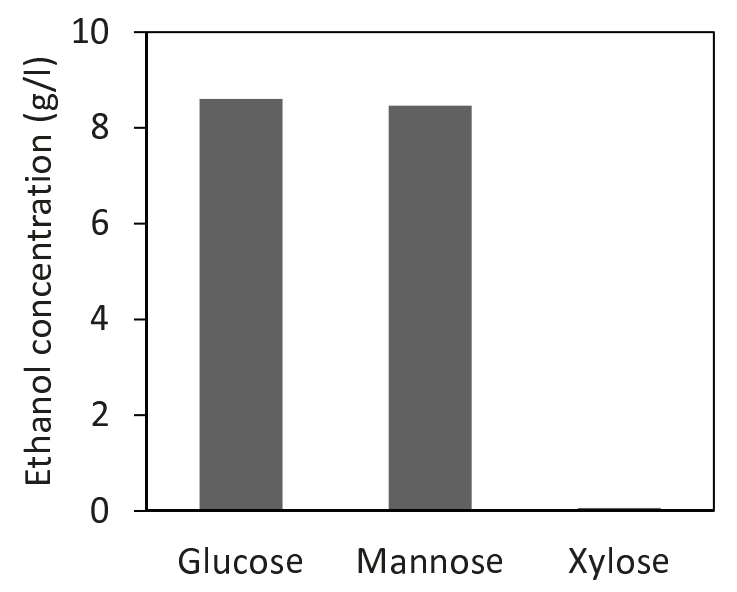

C

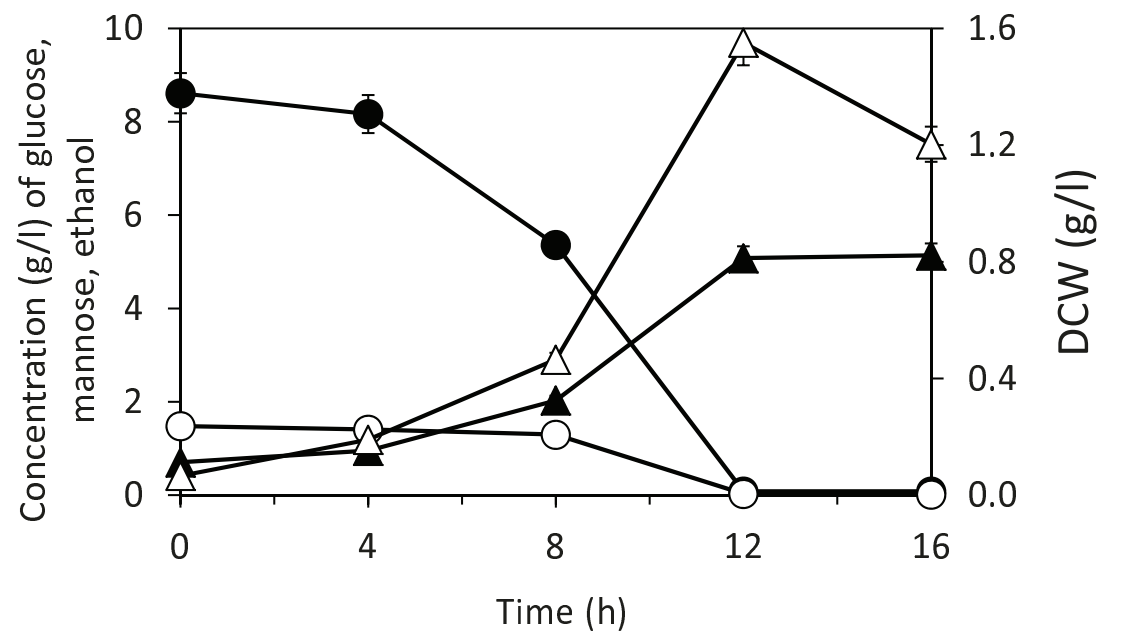

Figure 2 Enzymatic hydrolysis of paper sludge (PS) and ethanol production. (A) Monosaccharide composition of PS hydrolysate. (B) Ethano production using $20 \mathrm{~g} / \mathrm{l}$ of glucose, mannose and xylose. (C) Time course of monosaccharide and ethanol production from a mixed carbon source of $8.5 \mathrm{~g} / \mathrm{l}$ glucose and $1.5 \mathrm{~g} / \mathrm{l}$ mannose. Symbols in (C): closed circles = glucose; open circles = mannose; open triangles = dry cell weight (DCW); closed triangles = ethanol. Error bars in (C) denote $5 \%$ error of three repeated experiments. 


\section{Enzymatic hydrolysis of untreated PS using cellulase from PS origin}

To compare the hydrolytic performance between Acremonium cellulase (commercial origin) and cellulase produced from PS (PS origin), PS was hydrolysed using the same enzyme activity. Cellulase from PS origin was produced using PS in fermenter and obtained $900 \mathrm{ml}$ of supernatant containing cellulase, of which activity was 9 $\mathrm{FPU} / \mathrm{ml}$ (data not shown). The difference in RS concentration between using cellulase of PS origin and using commercial cellulase was negligible (Figure 3A) and its $Y_{\mathrm{s}}$ was $54 \%$ (g RS/g PSOM). This result shows that the cellulase from PS origin performs similarly to commercial cellulase and can be used for the enzymatic hydrolysis of PS. The optimum conditions found for obtaining the highest RS concentration were $110 \mathrm{~g}$ PSOM/l with 80.28 FPU/g PSOM (Figure 3B). The RS prediction was $43.79 \mathrm{~g} / \mathrm{l}$ with a $95 \%$ prediction interval (PI), $33.49 \mathrm{~g} / \mathrm{l}$ in low and $54.09 \mathrm{~g} / \mathrm{l}$ in high. According to analysis of variance (ANOVA) analysis, the model is significant. In order to confirm this prediction hydrolysis of PS was conducted on a flask scale using 110 g PSOM with 66 FPU/g PSOM. The concentrations of RS and glucose increased to $45.21 \mathrm{~g} / \mathrm{l}$ and $29.2 \mathrm{~g} / \mathrm{l}$, respectively, and the
$Y_{\mathrm{s}}$ was $41.1 \%$ (g RS/g PSOM). These values are in the range of the optimized prediction.

\section{Comparison of ethanol production between SHF and SSF}

SHF was carried out using conditions of $50 \mathrm{~g} / \mathrm{l}$ of PSOM with $15 \mathrm{FPU} / \mathrm{g}$ PSOM cellulase. After $48 \mathrm{~h}$ of saccharification, RS and glucose concentrations were 20 and 12.9 g/l, respectively (Figure 4A). Yeast inoculation (10\%) then initiated fermentation at a culture time of $60 \mathrm{~h}$; at this time glucose was diluted as a result of the inoculum, which was $10.7 \mathrm{~g} / \mathrm{l}$. The DCW of the yeast was below $1 \mathrm{~g} / \mathrm{l}$ (Figure 4B) and the ethanol concentration produced was $5.02 \mathrm{~g} / \mathrm{l}$ (Figure $4 \mathrm{C}$ ). The $Y_{\mathrm{e} / \mathrm{glc}}, Y_{\mathrm{e} / \mathrm{hex}}$, and $Y_{\mathrm{e} / \mathrm{psom}}$ were $92.1 \%$ (g ethanol/g consumed glucose), 26.9\% (g ethanol/g initial hexose) and 10.0\% (g ethanol/ g PSOM), respectively.

In SSF, under conditions of $50 \mathrm{~g} / \mathrm{l}$ PSOM with 15 FPU/g PSOM cellulase and 10\% inoculum, the glucose and RS concentrations increased up to $4 \mathrm{~h}$ (Figure 4A). During the subsequent time period, the DCW increased to $0.6 \mathrm{~g} / \mathrm{l}$ at $12 \mathrm{~h}$ and reached $12 \mathrm{~g} / \mathrm{l}$ at $44 \mathrm{~h}$ (Figure $4 \mathrm{~B}$ ). The glucose concentration was found to be almost $0 \mathrm{~g} / \mathrm{l}$ (Figure 4A), indicating that saccharification was the limiting step in ethanol production. The ethanol

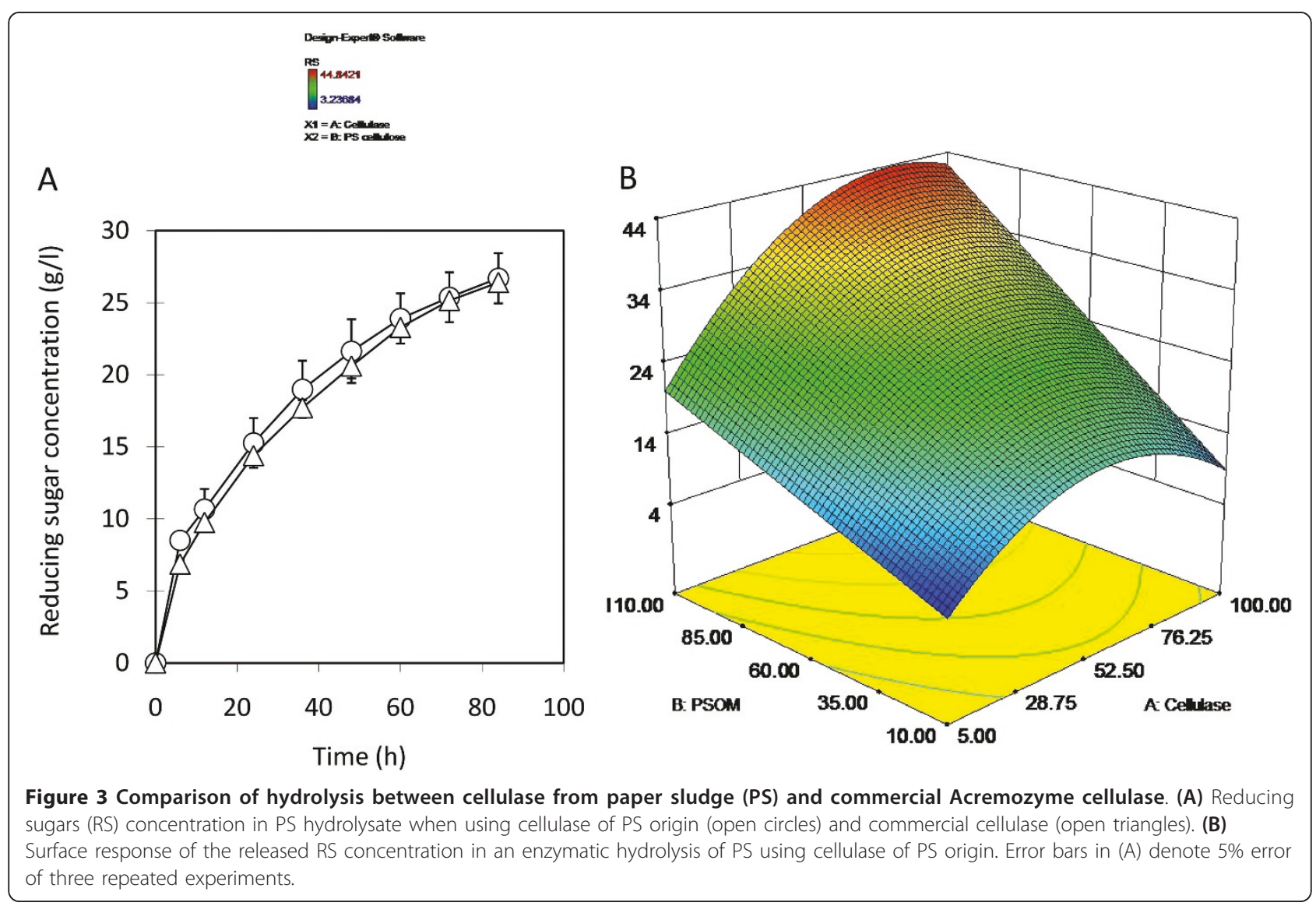



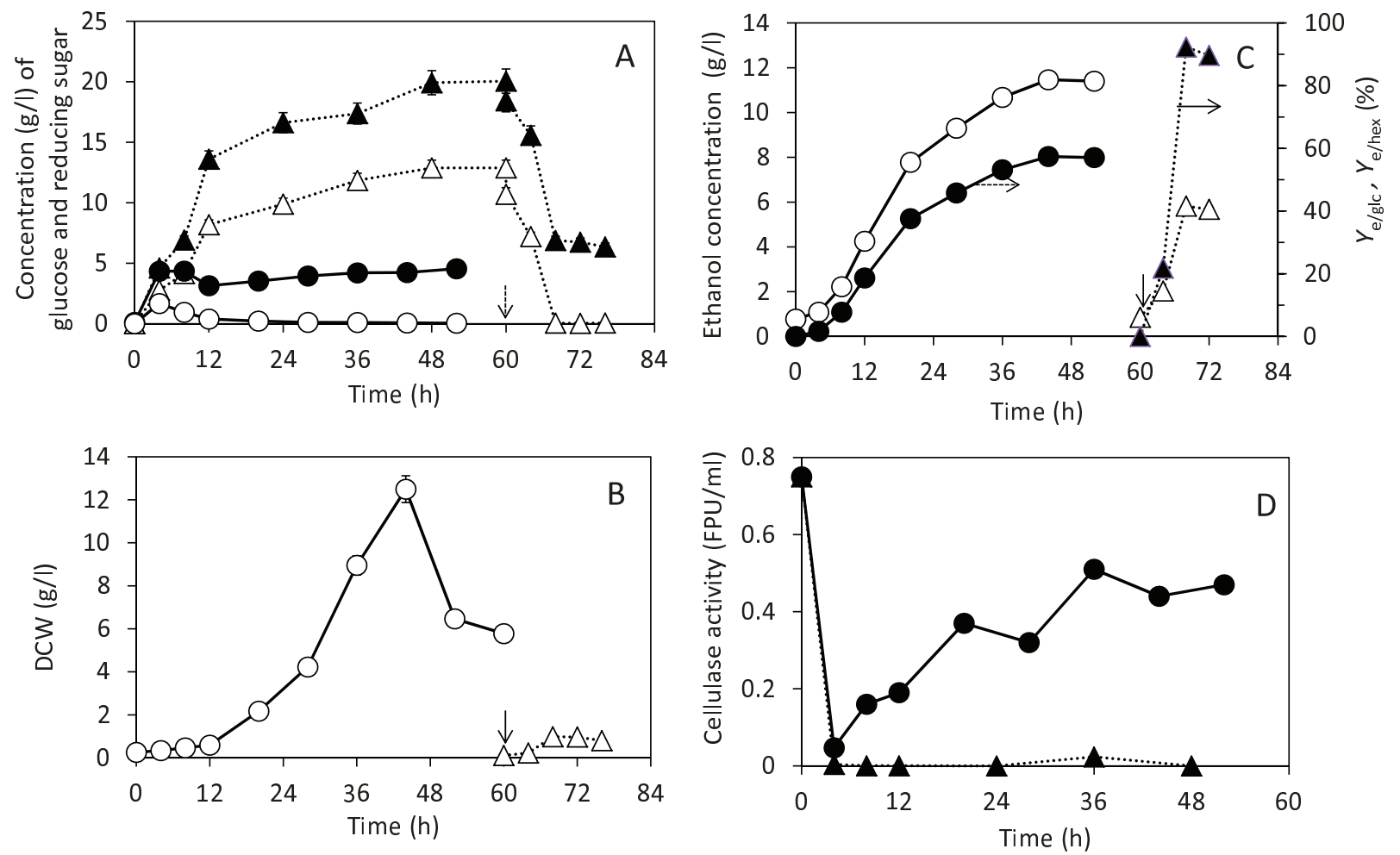

Figure 4 Comparison of glucose and reducing sugars (RS) (A), dry cell weight (DCW) (B), ethanol concentration and ethanol yields, $Y_{\mathrm{e} /}$ hex or $Y_{\mathrm{e} / \mathrm{glc}}$ (C) and remaining cellulase activity (D) in separate hydrolysis and fermentation (SHF) and simultaneous saccharification and fermentation (SSF). A total of $50 \mathrm{~g} / \mathrm{l}$ paper sludge organic material (PSOM) and $15 \mathrm{FPU} / \mathrm{g}$ PSOM were used for ethanol production. In the case of SHF the saccharification was stopped at $60 \mathrm{~h}$ (arrow) and initiated ethanol production by inoculation of 10\% preculture of S. cerevisiae TJ14. Symbols in (A): closed triangles = RS of SHF; open triangles = glucose of SHF; closed circles = RS of SSF; open circles = glucose of SSF. Symbols in (B): open circles = DCW of SSF; open triangles = DCW of SHF. Symbols in (C): open circles = ethanol of SSF; open triangles = ethanol of SHF; closed circles $=Y_{\mathrm{e} / \text { hex }}$ of SSF; closed triangles $=Y_{\mathrm{e} / \mathrm{glc}}$ of SHF. Symbols in (D): closed circle $=$ cellulase activity in SSF; closed triangles $=$ cellulase activity in SHF. Solid and dotted lines denote SSF and SHF, respectively. Error bars in (A) and (B) denote 5\% error of three repeated experiments.

concentration reached $11.4 \mathrm{~g} / \mathrm{l}$ at $44 \mathrm{~h}$ (Figure $4 \mathrm{C}$ ). The maximum $Y_{\mathrm{e} / \mathrm{hex}}$ and $Y_{\mathrm{e} / \mathrm{psom}}$ were $57.4 \%$ and $21.4 \%$, respectively.

The cellulase activity was investigated at SHF and SSF. In SHF, the glucose or RS concentration was higher than $8 \mathrm{~g} / \mathrm{l}$ and $14 \mathrm{~g} / \mathrm{l}$ at $12 \mathrm{~h}$. High RS or glucose concentration might cause deactivation of cellulase $[23,24]$ (Figure 4D) because the hydrolysate rate decreased after that. However, during SSF, the enzyme activity remained at around $60 \%$ of initial activity (Figure 4D). However, the activity dropped below $10 \%$ of the initial activity before $4 \mathrm{~h}$ (Figure 4D). Initially, the glucose concentration was below $5 \mathrm{~g} / \mathrm{l}$ and therefore did not deactivate cellulase, but insoluble materials contained in PS, for example clay and cellulose, adsorbed the cellulase. Since cellulase activity was assayed only in the supernatant, the cellulase adsorbed on the surface of cellulose and clay was excluded from the cellulase assay. Therefore, in the first $4 \mathrm{~h}$, the measured cellulase activity was very low. However, at subsequent timepoints, with the progress of the hydrolysis of PSOM the cellulase detached from the surface of PSOM and insoluble materials and released to supernatant. As a result, the cellulase activity recovered.

These results show that SSF was preferable for ethanol production from PS. A method of semi-SSF that consisted of prehydrolysis and SSF was found to be unsuitable for this process, because of the long saccharification time and remaining high glucose concentration during reaction [6].

\section{Improved ethanol production in SSF}

In order to maximize ethanol concentration from PS, the PSOM amount (50-110 g/l) and cellulase activity (15-35 FPU/g PSOM) were optimized. Surface response (Expert design v. 7.1.6) showed ethanol production trends (Additional file 1) following the equation below: 


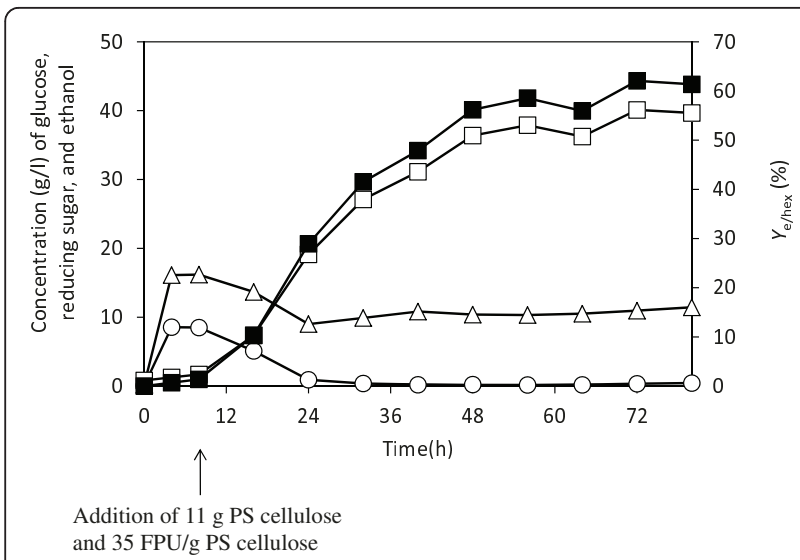

Figure 5 Confirmation of optimized ethanol production in simultaneous saccharification and fermentation (SSF). Symbols: open triangles = reducing sugars (RS); open circles = glucose; open squares $=$ ethanol; closed squares $=Y_{\text {e/hex }}$. Error bars denote $5 \%$ error of three repeated experiments.

$$
C_{e}=-1.43119+0.23436 \times C_{p s o m}+0.11351 \times E_{0}
$$

where $C_{\mathrm{psom}}$ and $E_{0}$ denote PSOM concentration and initial cellulase activity, respectively. ANOVA analysis was significant for the model and both parameters gave (Prob > F) less than 0.0001 for the model and the PSOM parameter, and (Prob $>$ F) $=0.0268$ for the cellulase parameter. From this simulation, experimental conditions of $170 \mathrm{~g} / \mathrm{l} \mathrm{PSOM}$ and $35 \mathrm{FPU} / \mathrm{g}$ PSOM were predicted to give the maximum ethanol concentration of $42.38 \mathrm{~g} / \mathrm{l}$ with $90 \%$ Prediction Interval (39.01 g/l for low and $45.75 \mathrm{~g} / \mathrm{l}$ for high). This was confirmed by experimental data. Since PSOM concentrations of more than $110 \mathrm{~g} / \mathrm{l}$ cause problems with mixing, SSF was carried out using initial conditions with $126.9 \mathrm{~g}$ PSOM/l, and 8.5 PSOM g was then added at $8 \mathrm{~h}$. Finally, the PSOM concentration was $170 \mathrm{~g}$ PSOM/l with cellulase of 35 FPU/g PSOM. The ethanol concentration reached 40.10
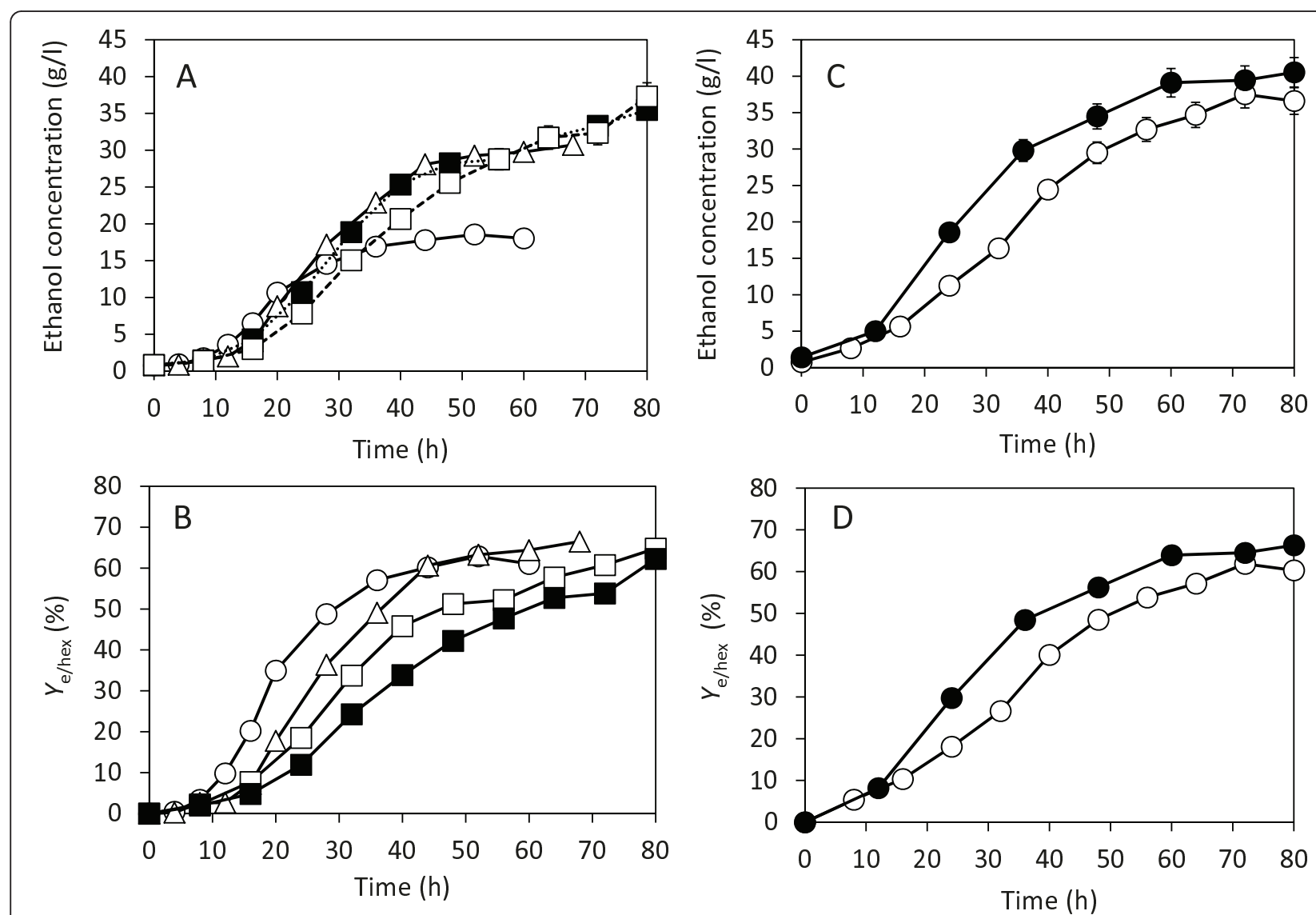

Figure 6 Simultaneous saccharification and fermentation (SSF) with increased paper sludge organic material (PSOM) concentration (A) and the theoretical ethanol yield $Y_{\mathrm{e} / \mathrm{hex}}(\mathrm{B})$, and SSF with increased inoculum size (C) and the theoretical ethanol yield $Y_{\mathrm{e} / \text { hex }}$ (D). (A, B) Initial conditions were $80 \mathrm{~g}$ PSOM/I and $15 \mathrm{FPU} / \mathrm{g}$ PSOM (open circles). PSOM (11 g, or $44.9 \mathrm{~g}$ PS) with PS cellulase 15 FPU/g PSOM was then added at $8 \mathrm{~h}$ (open triangles), at $8 \mathrm{~h}$ and $16 \mathrm{~h}$ (open squares), and at $8 \mathrm{~h}, 16 \mathrm{~h}$ and $20 \mathrm{~h}$ (closed squares). (C, D) Ethanol production increased inoculum size when $100 \mathrm{~g} \mathrm{PSOM} / \mathrm{I}$ and $15 \mathrm{FPU} / \mathrm{g}$ PSOM was used and with the addition of $11 \mathrm{~g} \mathrm{PSOM}$ with $15 \mathrm{FPU} / \mathrm{g}$ PSOM at culture times of 8 and 16 h. Symbols: open circles $=10 \% \mathrm{v} / \mathrm{v}$ inoculum; closed circles $=20 \% \mathrm{v} / \mathrm{v}$ inoculum. Error bars in (A) denote $5 \%$ error of three repeated experiments. 


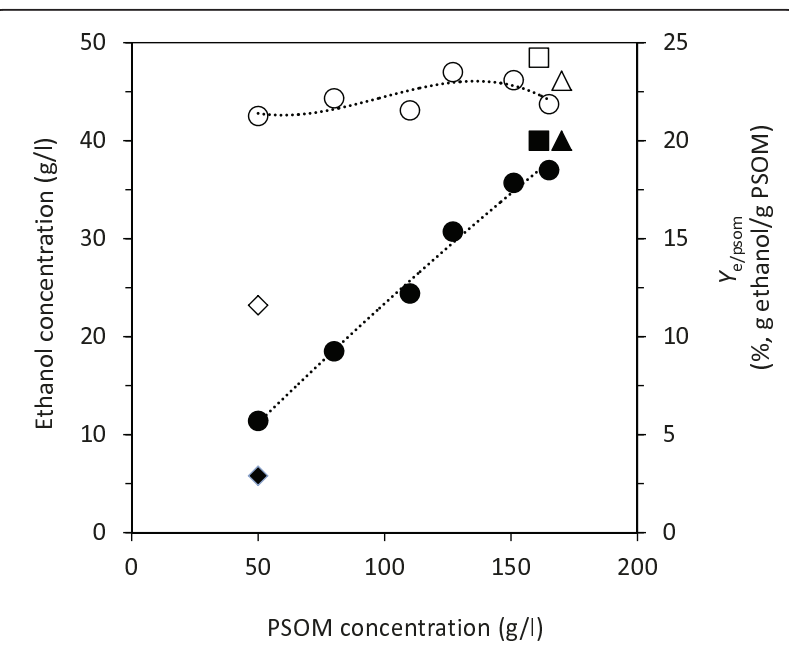

Figure 7 Ethanol yield $\left(Y_{\mathrm{e} / \mathrm{psom}}\right)$ and concentration in simultaneous saccharification and fermentation (SSF) for various paper sludge organic material (PSOM) concentrations. Data are cited from Figures 3-5. Symbols: closed circle = ethanol concentration; open circles $=Y_{\text {e/psom. }}$. Open and closed triangles denote $Y_{\text {e/psom }}$ and ethanol concentration, respectively, when increased PSOM with 35 FPU/g PSOM was used. Open and closed squares denote $Y_{e / p s o m}$ and ethanol concentration, respectively, when a $20 \%$ inoculum was used. Open and closed rhombuses denote $Y_{\mathrm{e} / \mathrm{psom}}$ and ethanol concentration of separate hydrolysis and fermentation (SHF), respectively.

$\mathrm{g} / \mathrm{l}$ under these conditions (Figure 5) and the $Y_{\mathrm{e} / \mathrm{hex}}$ was $62.5 \%$, which is within the range predicted by the model.

In order to minimize the amount of cellulase required, addition of PS and increasing the inoculum were tested. When $80 \mathrm{~g} / \mathrm{l}$ PSOM and $15 \mathrm{FPU} / \mathrm{g}$ PSOM cellulase were used, $18.5 \mathrm{~g} / \mathrm{l}$ of ethanol was obtained. To avoid depletion of PSOM, it was added in portions of $11.0 \mathrm{~g}$ PSOM (44.9 g PS) up to three times, resulting in final PSOM concentrations of 127, 151 and 165 g PSOM/l with 15 FPU/g PSOM cellulase, respectively. Ethanol concentrations achieved under these conditions were $30.7,35.7$ and $37.2 \mathrm{~g} / \mathrm{l}$, respectively (Figure 6A), of which theoretical ethanol yields $\left(Y_{\mathrm{e} / \mathrm{hex}}\right)$ were 63.0, 61.8, and 59.0\%, respectively (Figure $6 \mathrm{~B}$ ). No significant improvement was achieved when the addition was carried out two or

Table $3 Y_{s}$ estimated $64 \%$ based on experimental data; $192 \mathrm{~g}$ PSOM used

\begin{tabular}{ll}
\hline Factor & Estimated sugar amount $(\mathbf{g})$ \\
\hline Theoretical glucose needed & $38.8 \mathrm{~g} / \mathrm{l} / 0.51 \times 1.2 \mathrm{I}=91.3$ \\
RS at the end fermentation & $11 \mathrm{~g} / \mathrm{I} \times 1.2 \mathrm{I}=14.4$ \\
Glucose for yeast maintenance & $\mathrm{m}^{\mathrm{a}}(\mathrm{g} / \mathrm{g}$ cell/h) $\times 7.1 \mathrm{~g} / \mathrm{l} \times 72 \mathrm{~h}=17.5$ \\
Total RS in hydrolysate & 123 \\
Estimated $Y_{\mathrm{s}}(\%)$ & $123 / 192 \times 100=64.0$ \\
\hline
\end{tabular}

aWhere $m=0.034 \mathrm{~g}$ glucose $/(\mathrm{g}$ cell/h) [19].

PSOM = paper sludge organic material; RS = reducing sugars. three times. This suggests that the yeast concentration limited ethanol fermentation.

To solve this problem, the amount of inoculum used was increased to $20 \%$, with an initial PSOM concentration of $100 \mathrm{~g} / \mathrm{l}$, and two additions of $11.0 \mathrm{~g}$ PSOM (total PSOM concentration: $161 \mathrm{~g} / \mathrm{l})$. The ethanol concentration produced under these conditions increased from 35.7 to $40.5 \mathrm{~g} / \mathrm{l}$ (Figure $6 \mathrm{C}$ ) and $Y_{\mathrm{e} / \text { hex }}$ improved to $66.3 \%$. This process did not improve the ethanol production significantly. This was also confirmed in the 21 Erlenmeyer flask with a working volume of $1.2 \mathrm{l}$, and the ethanol concentration reached $38.8 \mathrm{~g} / \mathrm{l}$ with $Y_{\mathrm{e} / \mathrm{hex}}$ of $63.4 \%$ at a culture time of $72 \mathrm{~h}$ (data not shown).

\section{Discussion}

This study establishes a method for practical ethanol production from PS without any pretreatment. A process that produces a high ethanol concentration with a high ethanol yield from PS was targeted. When $50 \mathrm{~g} / \mathrm{l}$ of PSOM was used, the $Y_{\mathrm{e} / \mathrm{psom}}$ of SHF and SSF were 9.9 and $21.3 \%$ (g ethanol/g PSOM), respectively, but the ethanol concentration with SSF was $11.4 \mathrm{~g} / \mathrm{l}$. However, when the PSOM concentration was increased the ethanol concentration reached nearly $40 \mathrm{~g} / \mathrm{l}$. The ethanol concentration improved with increasing PSOM concentration, and the $Y_{\mathrm{e} / \mathrm{psom}}$ remained $24 \%$ (g ethanol/g PSOM) up to concentrations of $150 \mathrm{~g}$ PSOM/l (Figure 7). At PSOM concentrations higher than $160 \mathrm{~g} / \mathrm{l}$ in SSF, however, the process was hindered by mass transfer limitation. PSOM constitutes only $24.5 \%$ of PS, meaning that $160 \mathrm{~g}$ PSOM is equivalent to $653 \mathrm{~g}$ PS/l. It was found to be impossible to mix $653 \mathrm{~g} / \mathrm{l}$ of PS homogeneously, leading to decreased enzymatic hydrolysis performance. When $140 \mathrm{~g} / \mathrm{l}$ of PSOM was used initial ethanol productivity (up to $8 \mathrm{~h}$ ) decreased around $40 \%$ compared to that using $80 \mathrm{~g} / \mathrm{l}$ of PSOM (Additional file 2). This is evident from the decreased $Y_{\text {e/psom }}$ observed at $165 \mathrm{~g} / \mathrm{l}$ of PSOM. Higher ethanol concentration, more than $170 \mathrm{~g} / \mathrm{l}$ of PS should be handled.

In order to increase ethanol concentration, the PSOM concentration must be increased. To increase ethanol concentration to $40 \mathrm{~g} / \mathrm{l}$, two strategies were devised: increasing cellulase activity to solve glucose limitation, and increasing the fermentation inoculum to improve ethanol production. The cellulase activity was increased to $35 \mathrm{FPU} / \mathrm{g}$ PSOM to increase saccharification yield by around $5 \%$. The ethanol concentration increased from $37 \mathrm{~g} / \mathrm{l}$ to $40 \mathrm{~g} / \mathrm{l}$ and the $Y_{\mathrm{e} / \mathrm{psom}}$ also increased from 21 to $24 \%$ (g ethanol/g PSOM). When $20 \%$ of the inoculum was used, the ethanol concentration, $Y_{\mathrm{e} / \mathrm{psom}}$, and $Y_{\mathrm{e} / \mathrm{hex}}$ increased to $40.5 \mathrm{~g} / \mathrm{l}, 24.2 \%$, and $66.3 \%$, respectively. This result was similar to that of bioconversion of Kraft paper mill sludge to ethanol using SSF [24]. Ideal ethanol production from cellulose was observed for SF, since 


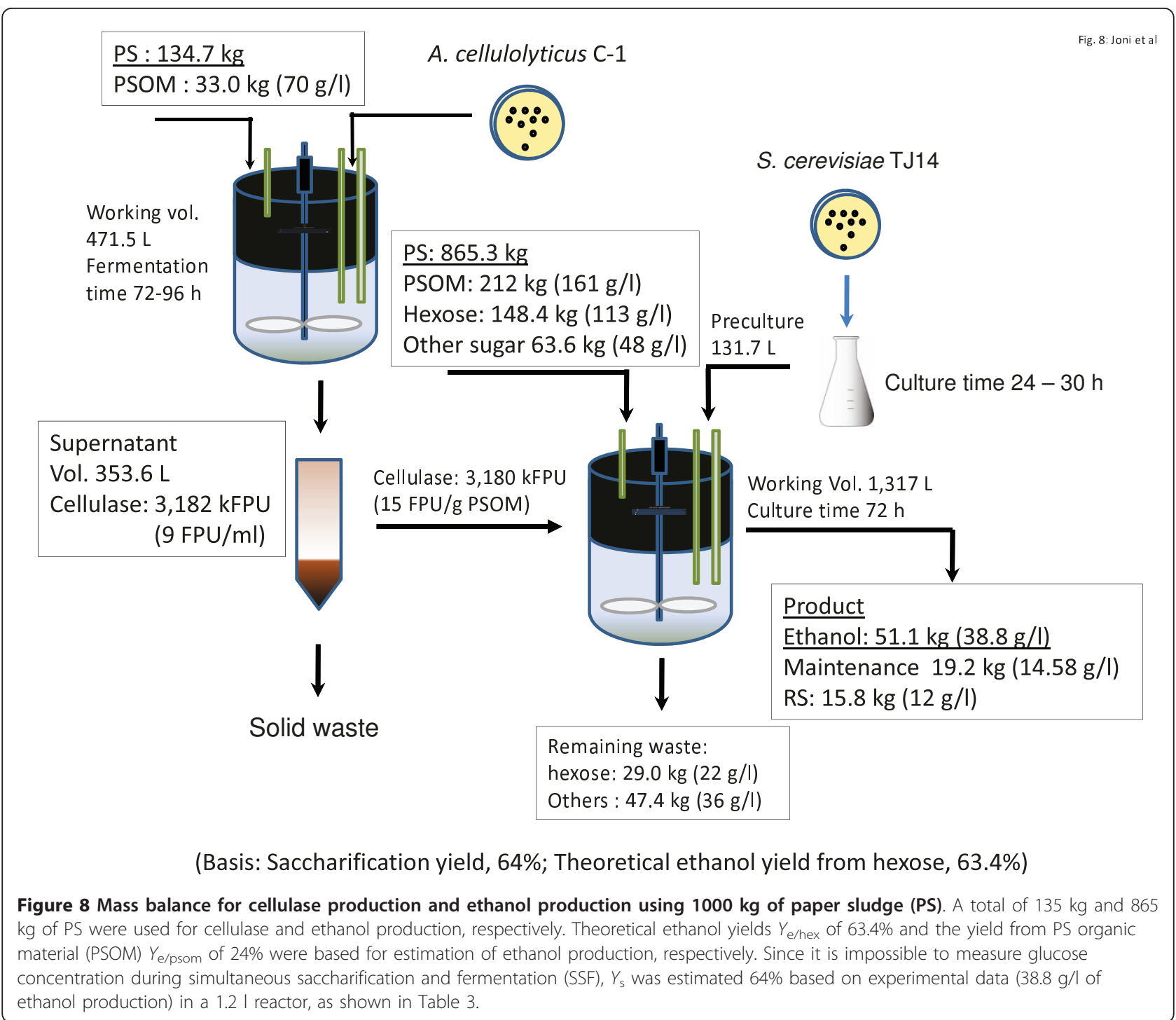

SF consists entirely of cellulose. $Y_{\mathrm{e} / \text { cellulose }}$ using $50 \mathrm{~g} \mathrm{SF} /$ I was $20.3 \%$ (data not shown), which is the same yield as that obtained using $50 \mathrm{~g}$ PSOM cellulose/l in SSF. Therefore, SSF of PS can be considered to be nearly the same as the ideal process using SF as carbon source.

Based on the 21 scale results ( $Y_{\mathrm{e} / \mathrm{hex}}$ of $63.4 \%$ ), a simple mass balance for ethanol production from PS was estimated (Figure 8). When 1 ton of PS is used in ethanol production, around $134.7 \mathrm{~kg}$ of PS is used for cellulase production. This cellulase is then used for the enzymatic hydrolysis of another $865.3 \mathrm{~kg}$ of PS and bioconverts PSOM to ethanol. The ethanol production is predicted to be about $51.1 \mathrm{~kg}$ based on $Y_{\mathrm{e} / \mathrm{psom}}$ of $23.5 \%$ (g ethanol/g PSOM). In Japan, around 5 million tons of PS is discarded annually, and if this amount were to be used for bioethanol production 255,000 tons of ethanol could be produced. A recent trend in automotive fuels involves the blending of ethanol (5\% to $10 \%)$ with gasoline $[25,26]$, as this allows the present fuel distribution infrastructure to be used largely unchanged. A total of 255,000 tons of ethanol could be blended at the $5 \%$ level with 5,100,000 tons of gasoline. The results of ethanol production from PS using PS cellulase produced by $A$. cellulolyticus described here demonstrates the potential of this process for future bioethanol production. Further studies are planned to allow ethanol production from PS to be scaled up.

\section{Conclusions}

The ethanol yield ( $\left.Y_{\text {e/psom }}\right)$ obtained when 50 to $150 \mathrm{~g}$ PSOM/l was used was $21 \%$ to $23 \%$ (g ethanol/g PSOM) in the SSF, which is two times higher than that obtained using SHF. Cellulase activity remained at around 60\% throughout SSF. Within the PSOM concentrations less 
than $160 \mathrm{~g}$ PSOM/l, the ethanol yield remained at $23 \%$ with the ethanol concentration of $40 \mathrm{~g} / \mathrm{l}$. Ethanol production of $40 \mathrm{~g} / \mathrm{l}$ was achieved using $161 \mathrm{~g} / \mathrm{l}$ of PSOM with $15 \mathrm{FPU} / \mathrm{g}$ PSOM and $20 \%$ inoculum, after $80 \mathrm{~h}$ using the optimized SSF process. This was confirmed in the $2 \mathrm{l}$ scale experiment and indicates that there is great potential to use PS as a raw material for ethanol production.

\section{Additional material}

\section{Additional file 1: Optimization of cellulase and paper sludge} organic material (PSOM) concentration for improving ethanol concentration. PSOM concentration and cellulase activity were optimized under the following conditions: initial PSOM concentrations were 50, 80 and $110 \mathrm{~g} / \mathrm{l}$ and cellulase activities were 15, 25 and $35 \mathrm{FPU} /$ $\mathrm{g}$ PSOM. After medium sterilization, the cellulase and $10 \%$ inoculum were added to $500 \mathrm{ml}$ Erlenmeyer flasks with final working volumes of $100 \mathrm{ml}$. Data were analyzed by Design Expert (v. 7.1.6, Stat-Ease, Minneapolis, MN, USA)

\section{Additional file 2: paper sludge (PS) appearance during} simultaneous saccharification and fermentation (SSF). (A), (B), and (C) denote PS appearance during SSF at 0,4 , and 8 h, respectively. (1) and (2) indicate PS organic material (PSOM) concentrations of 80 and $140 \mathrm{~g} / \mathrm{l}$, respectively. When $140 \mathrm{~g} / \mathrm{l}$ of PSOM was used it is impossible to mix culture broth. (D) Effect of initial PSOM concentration on ethanol production rate until $8 \mathrm{~h}$.

\section{Acknowledgements}

This study was supported by the Comprehensive Support Programs for Creation of Regional Innovation in Japan Science and Technology Agency (JST).

\section{Author details}

'Laboratory of Biotechnology, Integrated Bioscience Section, Graduate School of Science and Technology, Shizuoka University, 836 Ohya, Suruga-ku, Shizuoka 422-8017, Japan. ${ }^{2}$ Laboratory of Biotechnology, Faculty of Agriculture, Department of Applied Biological Chemistry, Shizuoka University, 836 Ohya, Suruga-ku, Shizuoka 422-8017, Japan. ${ }^{3}$ Department of Biotechnology, Faculty of Science, Mahidol University, Rama VI Road, Bangkok 10400, Thailand. ${ }^{4}$ Department of Biotechnology, Graduate School of Engineering, Osaka University, Osaka, Japan.

\section{Authors' contributions}

JP was responsible for the experimental design, and the hydrolysis and fermentation experiments. KN participated in measurement of cellulase activity and PS saccharification. HS and CB provided Saccharomyces cerevisiae TJ14. EYP directly supervised the project, participated in its experimental design, data interpretation, and was responsible for writing the manuscript. All authors read and approved the manuscript.

\section{Competing interests}

The authors declare that they have no competing interests.

Received: 31 May 2011 Accepted: 29 September 2011 Published: 29 September 2011

\section{References}

1. Prasetyo J, Kato T, Park EY: Efficient cellulase-catalyzed saccharification of untreated paper sludge targeting for biorefinery. Biomass Bioenerg 2010, 34:1906-1913.

2. Claassen PAM, van Lier JB, Contreras AML, van Niel EWJ, Sijtsma L, Stams AJM, de Vries SS, Weusthuis RA: Utilisation of biomass for the supply of energy carriers. Appl Microbiol Biotechnol 1999, 6:741-755.
3. Solomon BD, Barnes JR, Halvorsen KE: Grain and cellulosic ethanol: history, economics, and energy policy. Biomass Bioenerg 2007, 6:416-425.

4. Yamashita Y, Sasaki C, Nakamura Y: Development of efficient system for ethanol production from paper sludge pretreated by ball milling and phosphoric acid. Carbohyd Polym 2010, 79:250-254.

5. Larsson S, Palmqvist E, Hahn-Hagerdal B, Tengborg C, Zacchi G, Nilvebrant NO: The generation of fermentation inhibitors during dilute acid hydrolysis of softwood. Enzyme Microb Technol 1999, 24:151-159.

6. Ranatunga TD, Jervis J, Helm RF, McMillan JD, Wooley RJ: The effect of overliming on the toxicity of dilute acid pretreated lignocellulosics: the role of inorganics, uronic acids and ether-soluble organics. Enzyme Microb Technol 2000, 27:240-247.

7. Shen J, Agblevor FA: Ethanol production of semi-simultaneous saccharification and fermentation from mixture of cotton gin waste and recycled paper sludge. Bioproc Biosyst Eng 2010, 34:33-43.

8. Matsushika A, Inoue H, Kodaki T, Sawayama S: Ethanol production from xylose in engineered S. cerevisiae strain: current state and perspectives. Appl Microbiol Biotechnol 2009, 84:37-53.

9. Erdei B, Barta Z, Sipos B, Reczey K, Galbe M, Zacchi G: Ethanol production from mixtures of wheat straw and wheat meal. Biotechnol Biofuel 2010, 3:16.

10. Fan Z, South C, Lyford K, Munsie J, van Walsum P, Lynd LR: Conversion of paper sludge to ethanol in semi continuous solid fed reactor. Bioproc Biosyst Eng 2003, 26:93-101

11. Moukamnerd C, Kino-oka M, Sugiyama M, Kaneko Y, Boonchird C, Harashima S, Noda H, Ninomiya K, Shioya S, Katakura Y: Ethanol production from biomass by repetitive solid-state fed-batch fermentation with continuous recovery of ethanol. Appl Microbiol Biotechnol 2010, 88:87-94.

12. Prasetyo J, Zhu J, Kato T, Park EY: Efficient production of cellulase in the culture of $A$. cellulolyticus using untreated waste paper sludge. Biotechnol Progr 2011, 1:104-110.

13. Ando T, Sakamoto T, Sugiyama O, Hiyoshi K, Matsue N, Henmi T: Adsorption mechanism of $\mathrm{Pb}$ on paper sludge ash treated by $\mathrm{NaOH}$ hydrothermal reaction. Clay Sci 2004, 12:243-248.

14. Ikeda Y, Hayashi H, Okuda N, Park EY: Efficient cellulase production by the filamentous fungus A. cellulolyticus. Biotechnol Progr 2007, 23:333-338.

15. Yamanobe T, Mitsuishi Y, Takasaki Y: Isolation of cellulolytic enzyme producing microorganism, culture conditions and some properties of the enzymes. Agric Biol Chem 1987, 51:65-74.

16. Kansarn S: A novel concept for the enzymatic degradation mechanism of native cellulose by $A$. cellulolyticus.[http://hdl.handle.net/10297/1453].

17. Sugiyama M, Benjaphokee $S$, Auesukaree C, Asvarak T, Boonchird C, Harashima $\mathrm{H}$ : Yeast carbon neutral biotechnology,-high-temperature and acid tolerant strain for high-level bioethanol production. Proceedings of the Thailand-Japan Joint Symposium on Bioproduction by efficient utilization of Thai resources in the 20th Annual Meeting of The Thai Society for Biotechnology: Biotechnology for Health Care, 2008 Maha Sarakham University, Maha Sarakham, Thailand; 2008, 14-17.

18. Brachmann CB, Davies A, Cost GJ, Caputo E, Li J, Hieter P, Boeke JD: Designer deletion strains derived from S. cerevisiae S288C: a useful set of strains and plasmids for PCR-mediated gene disruption and other applications. Yeast 1998, 14:115-132.

19. Zhang j, Shao X, Townsend OV, Lynd LR: Simultaneous saccharification and co-fermentation of paper sludge to ethanol by Saccharomyces cerevisiae RWB222-part I: kinetic modelling and parameters. Biotechnol Bioeng 2009, 5:920-931.

20. Ghose TK: Measurement of cellulase activities. International Union of Pure and Applied Chemistry. Pure Appl Chem 1987, 59:257-268.

21. Sluiter A, Hames B, Ruiz R, Scarlata C, Sluiter J, Templeton D: Determination of Structural Carbohydrates and Lignin in Biomass Golden, CO, USA: National Renewable Energy Laboratory; 2004.

22. Shuler ML, Kargi F: Bioprocess Engineering: Basic Concepts Englewood Cliffs, NJ, USA: Prentice Hall PTS; 1992, 207-208.

23. Zhang J, Heiss $C$, Thorne PG, Bal C, Azadi P, Lynda LR: Formation of ethyl $\beta$-xylopyranoside during simultaneous saccharification and $\mathrm{co}-$ fermentation of paper sludge. Enz Microb Technol 2009, 44:192-202.

24. Kang L, Wang W, Lee YY: Bioconversion of kraft paper mill sludges to ethanol by SSF and SSCF. Appl Bichem Biotechnol 2010, 161:53-66.

25. Rehnlund $B$ : Blending of ethanol in gasoline for spark ignition engines. [http://www.eri.ucr.edu/ISAFXVCD/ISAFXVAB/BEGSIE.pdf]. 
26. Egeback KE, Henke M, Rehnlund B, Wallin M, Westerholm R: Blending of ethanol in gasoline for spark ignition engines: Problem inventory and evaporative measurement. AVL-MTC, 2005, Report number MTC 5407, ISSN 1103-0240, ISRN: ASB-MTC-R-05/2-SE [http://www.growthenergy.org/images/ reports/avl_ethanol_sparkignition.pdf].

doi:10.1186/1754-6834-4-35

Cite this article as: Prasetyo et al:: Bioconversion of paper sludge to biofuel by simultaneous saccharification and fermentation using a cellulase of paper sludge origin and thermotolerant Saccharomyces cerevisiae TJ14. Biotechnology for Biofuels 2011 4:35.

Submit your next manuscript to BioMed Central and take full advantage of:

- Convenient online submission

- Thorough peer review

- No space constraints or color figure charges

- Immediate publication on acceptance

- Inclusion in PubMed, CAS, Scopus and Google Scholar

- Research which is freely available for redistribution

Submit your manuscript at www.biomedcentral.com/submit
Ciomed Central 